\title{
Users Acceptance of Mobile Finance Service in Bangladesh and the impact of COVID-19: Extended UTAUT2
}

\begin{abstract}
Manzur Hossain Khan, SQS-CAS, Universiti Utara Malaysia, Malaysia, Nurakmal Ahmad Mustaffa, SQS-CAS, Universiti Utara Malaysia, Malaysia, Md. Mamun Habib, Independent University Bangladesh, Bangladesh.
\end{abstract}

\begin{abstract}
Population of Bangladesh is around 166 million, but there are almost 175 million mobile phone subscribers. Mobile phone usage is one of the fastest growing phenomena of the country. Globally, among many mobile based services, Mobile Financing is one of the most rapidly expanding sector. Bangladesh is yet to see a significant growth in this arena. There are numerous studies conducted on types of Mobile Financing Services (MFS) and their reach in Bangladesh. But not too many studies were conducted on the factors that influences users to adopt MFS and their behavioral intension. Moreover, the recent crisis of COVID-19 pandemic seemed to have an impact on the usage of MFS which is also another unexplored research domain. This study analyzes the factors influencing MFS users of Bangladesh and also explores the impact of COVID-19 on the user's behavioral intension. The Unified Theory of Acceptance and Use of Technology (UTAUT) model in combination with Entrepreneurial Potential Model has been modified and adopted in this study. This study explores the correlation of Performance Expectancy (PE), Effort Expectancy (EE), Social Influence (SI), Facilitating Conditions (FC), Price Value (V) on Behavioral Intention (BI) on MFS users. It also studies the moderation effect of COVID-19 on the relationship between MFS users' Behavioral Intension and Use Behavior. The correlating factors effect positively on the MFS users' behavioral intention. But the COVID-19 impact was found ineffective in moderating their use behavior. The framework of this research is a novel one and can be adopted for similar studies.
\end{abstract}

Index Terms - COVID-19 impact, Mobile Finance Service (MFS), UTAUT2, Entrepreneurial Potential Model (EPM), Regression-based Moderation Analysis.

Manzur Hossain Khan is a PhD student at the School of Quantitative Sciences, Universiti Utara Malaysia, Malaysia

Nurakmal Ahmad Mustaffa is a Senior Lecturer of the School of

Quantitative Sciences, Universiti Utara Malaysia, Malaysia

Md. Mamun Habib is a Professor of the School of Business, Independent University, Bangladesh

\section{INTRODUCTION}

Bangladesh is one the rapidly developing country of the South Asia region where mobile phone services were launched in 1993 [1]. Since then, the subscription has grown over the years exponentially. In January 2021, the mobile phone subscribers (almost 175 million), [2] are even higher than the total population (almost 166 million) [3], of the country. Currently, the overall mobile services and mobile based services are in critical situation in Bangladesh. Even though the traditional consumer banking service did not see significant growth, mobile finance service has increased very significantly from 2 million clients in 2012 [4] to 102 million in 2021 [5]. One of the contributing factors behind this growth is the increasing number of mobile internet users of the country which has reached almost 117 million in January 2021 [6].

With the guideline of Bangladesh Bank the Mobile Finance Services (MFS) started in Bangladesh in 2011. The Dutch Bangla Bank was the first to initially launched MFS [1]. At the moment 15 banks provide MFSs [5] and reaches out to the people who are not under the traditional financial services [4]. In a study conducted by Bangladesh Bank in 2017 titled 'An Impact Study on Mobile Financial Services (MFSs) in Bangladesh' illustrates the following services which are provided by these institutions, Cash-in, Cash-out, Money Transfer, Shopping, Pay Bill, Mobile Top-up, others through MFS [7].

A. Research Objectives:

1) To study the factors influencing the behavioral intention and use behavior of the Mobile Finance Service users in Bangladesh.

2) To study the impact of COVID-19 on the relationship between behavioral intention and user behavior of Mobile Finance Service users in Bangladesh. 


\section{LITERATURE REVIEW}

In 2011, the Boston Consulting Group did a study titled 'The socio-economic impact of mobile financial services: Analysis of Pakistan, Bangladesh, India, Serbia and Malaysia'. It was identified that life of around 2 Billion people in the developing area could be enhanced by MFS at the time had they been provided MFS. At the initial stages of MFS in Bangladesh it was found that mobile banking system is highly used in Bangladesh regarding bill payment, savings and remittance, not so significant in the areas of credit and insurance, which more or less still the scenario at present [8].

There have been numerous researches conducted over the years, like, Parvin, A. (2013), Islam, S. (2013), [4], [9] conducted on different aspects of mobile banking in Bangladesh. Sadia et al. [4]'s research focused on the questions related to the individual level factors (like, education, age, etc.) that influence the adoption of mobile banking services in Bangladesh. Tareq (2020) highlighted various service innovation and extension of banking through m-banking. He also explored the reach of MFS in different demographic settings. Islam, et. al. [10] conducted a similar research on Mobile Banking using UTAUT model to explore a framework. In 2017, the Bangladesh Bank in collaboration with the University of Dhaka conducted an 'Impact Study on Mobile Financial Services (MFSs) in Bangladesh' where factors affecting the households and small and medium business firms were covered extensively along with the service quality of MFS [7]. One of the aspects that was predicted in the initial study of Boston Consulting Group in 2011 was well observed in this 2017 study of Bangladesh Bank is that how MFS supports the low-income group of the country to deal with two of their primary financial challenges. One, to deal with high income volatility by building small saving buffers and increasing inflow remittances. Two, to mediate severe expense shock by obtaining funds to overcome temporary deficits. Thus, the MFS is contributing among the unbanked low-income group in improving their economic situation.

Even though most of the above-mentioned studies were conducted to explore various factors of MFS in Bangladesh, but unfortunately none of them is conducted from the point of view of technology service users based on any established model of use of technology or its influencing factors. This study is based on the Unified Theory of Acceptance and Use of Technology (UTAUT2) [11] to study the influencing factors of Mobile Finance Services on the users of Bangladesh- in terms of stakeholders' behavioral intention effected by performance expectancy, effort expectancy, social influence, price value and facilitating condition. Moreover, the uniqueness of this study is incorporating the impact of ongoing COVID-19 pandemic on the behavioral intension of MFS users. To assess this additional factor in this study the Entrepreneurial Potential Model [12] is incorporate with UTAUT2.

Like the rest of the world, Bangladesh has been severely affected by COVID-19 pandemic since March 2020. Officially, the first case of coronavirus infection was reported on March 8, 2020 [13]. From March 17, 2020, all educational institutes of the country are physically shutdown. Schools, colleges, and universities with strong digital infrastructure managed to transform their operations in online platform. But unfortunately, majority others failed to run their operations uninterrupted and still struggling [14]. Many other types of organizations have also shifted to online operations. Online and mobile based services have become a regular phenomenon. The economic activities started operating on limited scale due to restrictions imposed on the social movement. This unprecedented event has substantially impact on the economic growth and prosperity. Numerous businesses were forced to shut down and unemployment rate increased exponentially. There is a massive impact on the livelihood of general people. The uncertainty of covid-19 interfered the economic development, and the degree of interference is almost impossible to determine [15].

\section{A. Unified Theory of Acceptance and Use of Technology (UTAUT2)}

Since the early days, there were numerous studies conducted to research the acceptance of technology by the stakeholders. In 2003, Venkatesh, Morris, B.Davis, \& D.Davis (2003) eventually combined eight different well-known technology acceptance models and came up with the Unified Theory of Acceptance and Use of Technology (UTAUT). The models UTAUT was inspired by are [16]:

1) Innovation Diffusion Theory (IDT)

2) Theory of Reasoned Action (TRA)

3) Theory of Planned Behavior (TPB)

4) Technology Acceptance Model (TAM)

5) Model of PC Utilization (MPCU)

6) Motivational Model (MM)

7) Model combining TAM and TPB

8) Social Cognitive Theory (SCT)

The Unified Theory of Acceptance and Use of Technology (UTAUT) [17] is widely used by researchers to study and measure technology use and adoption [18]; [19]. Some of the limitations of UTAUT was later addressed in the UTAUT2 model [11] with three additional constructs (hedonic motivation, price value and habit) being included with the existing (facilitating conditions, performance expectancy, effort expectancy and social influence and). Based on the type of research domain and nature, researchers used a combination 
of all or several of the UTAUT2 constructs to investigate the Technology acceptance and adoption in numerous fields, like, education, e-governance, mobile device, etc. [20];[21]; [22]; [23]; [24]; [25]; [26].

In a study to identify the determinants of IT related innovation acceptance and use behavior Sedigheh Moghavvemi, et al., integrated UTAUT and Entrepreneurial Potential Model in 2012 [12], where Precipitating Events is used as a construct which modifies the ultimate use behavior. Entrepreneurial Potential Model (EPM) is based on the Entrepreneurial Event Model and further updated through additional researches conducted by Krueger and Brazeal [27], [28] where the precipitating events in EPM is defined as certain externally derived variable that facilitates or "precipitates" the transformation of user intention into behavior.

\section{RESEARCH FRAMEWORK}

With the combination of the above-mentioned concepts, the research framework of this study is as following:

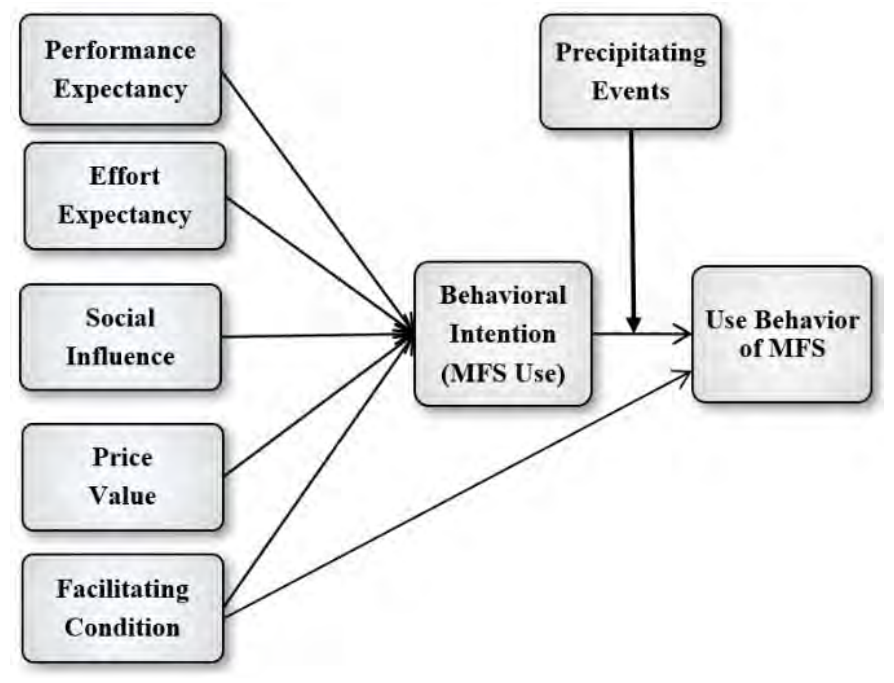

Fig. 1: Research Framework (Adopted from [11], [29])

The UTAUT2 is used to explore the relationship between the following constructs:

Performance Expectancy (PE): The extent of an individual's belief that using the system will be advantageous. [11]

Effort Expectancy (EE): The ease of using technology [30]. Social Influence (SI): The extent of influence of those people who are important to the participant in accepting the new technology [11].

Facilitating Conditions (FC): The assessment of organizational and technical infrastructure to support the use of technology [17].

Price Value (V): The assessment of the resources spent, and perceived value gained from using the technology [17].
Behavioral Intention (BI): The individual's intention to voluntarily perform a given act and predict corresponding behaviors [31].

Precipitating Events (PEV): Effect of sudden change in environment on the perception of individual's decision to accept new technology. It captures the effect of external factors on user's intention to act and is considered as a moderator on the connection between intention and behavior [28]. Schindehutte et al. [32] categorized such moderating triggers into five key dimensions: opportunity- driven vs. threat-driven, market pull vs. technology push, internal vs. external (to organization), top-down vs. bottom-up, systematic or deliberate search vs. chance or opportunism [32]; [29]. In this study, the authors posit how environmental and external factors and unforeseen events can change user's intention.

\section{RESEARCH METHODOLOGY}

Based on the model, a questionnaire was developed to determine the MFS users' behavioral intention toward technology adoption and how precipitating events modifies it towards the actual use behavior. Likert scales (1-5) ranging from 'strongly agree' to 'strongly disagree' was used for all construct items. An online survey was conducted where 839 valid responses from 1035 total number of responses were considered, taken from randomly chosen MFS users from various demographics settings with a response rate of $81.06 \%$. Appendix 1 summarizes the profile of the respondents and some interesting demographic observation. The data presented in Tables II - X and Figure 2 were analyzed and tested using SPSS software.

Some of the important and interesting demographic (social and cultural) observations are -

1) Majority of the MFS users are from lower income group

2) Female users tend to use more multiple number of MFSs

3) Bkash is the top MFS by a large margin

More detail of demography is available in Appendix 1.

To measure the reliability of data, Cronbach's alpha was measured in multiple ways. Cronbach's alpha calculates the internal consistency measuring how closely related the items are as a group. It is a measure of scale reliability. Cronbach's alpha value ranges from 0 to 1 . Cronbach's alpha value of 0.6 or more is considered to be reliable [37].

To measure the correlation among the variables, Pearson's correlation ( $r$ ) method was used where the value of $r$ may vary from -1 to $+1 ; 0$ means no relationship, greater than 0 indicates positive relationship and less than 0 indicates negative relationship [33].

To identify the moderation effect of precipitating events on the relationship between behavioral intension and use behavior, regression-based Moderation Analysis was conducted with the PROCESS 3.5 plugin in SPSP developed by Andrew F. Hayes. 
The moderation analysis was conducted and interpreted with the following equation and reference value [34], [35]:

$$
\hat{Y}=b_{0}+b_{1} X+b_{2} W+b_{3} X W
$$

- $\quad$ whether the probability value, 'p' value of interaction of moderator and independent variables is significant $(<0.01)$ or not

- whether ' 0 ' falls between interaction's lower level of confidence interval (LLCI) and upper level of confidence interval (ULCI) or not.

- whether the value of coefficient determination $\mathrm{R}^{2}$, a statistical measure of fit that indicates amount of variation of a dependent variable is explained by the independent variable(s) in a regression model is significant $(>0.01)$ or not

- whether there are variations in the graphs represented with the low, medium and high value of the moderator on its effect on the relationship between independent variable and the dependent one.

\section{RESULTS AND DisCUSSIONS}

A. Data Reliability:

Table I

RELIABILITY STATISTICS

\begin{tabular}{|c|c|c|c|}
\hline \multicolumn{2}{|c|}{$\begin{array}{c}\text { Among all Items } \\
\text { of all the variable }\end{array}$} & \multicolumn{2}{c|}{$\begin{array}{c}\text { Among the Sum } \\
\text { of Variables }\end{array}$} \\
\hline $\begin{array}{c}\text { Cronbach's } \\
\text { Alpha }\end{array}$ & $\begin{array}{c}\text { N of } \\
\text { Items }\end{array}$ & $\begin{array}{c}\text { Cronbach's } \\
\text { Alpha }\end{array}$ & $\begin{array}{c}\text { N of } \\
\text { Items (Sum) }\end{array}$ \\
\hline 0.941 & 31 & 0.914 & 8 \\
\hline
\end{tabular}

Table II

RELIABILITY AMONG THE INDIVIDUAL ITEMS IN EACH VARIABLE

\begin{tabular}{|l|l|l|}
\hline Variables & $\begin{array}{l}\text { Cronbach's } \\
\text { Alpha }\end{array}$ & $\begin{array}{l}\text { No. of } \\
\text { items }\end{array}$ \\
\hline Performance Expectancy (PE) & 0.878 & 4 \\
\hline Effort Expectancy (EE) & 0.850 & 5 \\
\hline Social Influence (SI) & 0.703 & 3 \\
\hline Facilitating Conditions (FC) & 0.742 & 4 \\
\hline Value (VL) & 0.734 & 4 \\
\hline Precipitating events (PEV) & 0.709 & 3 \\
\hline Behavioral Intention (BI) & 0.709 & 3 \\
\hline Use Behavior (UB) & 0.698 & 3 \\
\hline
\end{tabular}

All the items of the variable were found reliable with minimum Cronbach's Alpha value of 0.703 (Table I and II) [36]

\section{B. Correlation (Pearson's)}

\section{TABLE III}

\section{CORRELATION (PEARSON'S) AMONG VARIABLES AND} BEHAVIORAL INTENTION (BI)

\begin{tabular}{|l|c|c|c|c|}
\hline Items & BI1 & BI2 & BI3 & BI (SUM) \\
\hline PE1 & $0.229^{* *}$ & $0.405^{* *}$ & $0.322^{* *}$ & $0.442^{* *}$ \\
\hline PE2 & $0.229^{* *}$ & $0.405^{* *}$ & $0.322^{* *}$ & \\
\hline PE3 & $0.265^{* *}$ & $0.439^{* *}$ & $0.328^{* *}$ & \\
\hline PE4 & $0.332^{* *}$ & $0.396^{* *}$ & $0.384^{* *}$ & \\
\hline EE1 & $0.346^{* *}$ & $0.450^{* *}$ & $0.371^{* *}$ & $0.615^{* *}$ \\
\hline EE2 & $0.296^{* *}$ & $0.530^{* *}$ & $0.315^{* *}$ & \\
\hline EE3 & $0.317^{* *}$ & $0.470^{* *}$ & $0.360^{* *}$ & \\
\hline EE4 & $0.321^{* *}$ & $0.517^{* *}$ & $0.354^{* *}$ & \\
\hline EE5 & $0.357^{* *}$ & $0.485^{* *}$ & $0.384^{* *}$ & \\
\hline SI1 & $0.417^{* *}$ & $0.375^{* *}$ & $0.355^{* *}$ & $0.607^{* *}$ \\
\hline SI2 & $0.319^{* *}$ & $0.463^{* *}$ & $0.347^{* *}$ & \\
\hline SI3 & $0.377^{* *}$ & $0.397^{* *}$ & $0.410^{* *}$ & \\
\hline FC1 & $0.397^{* *}$ & $0.366^{* *}$ & $0.390^{* *}$ & $0.634^{* *}$ \\
\hline FC2 & $0.338^{* *}$ & $0.435^{* *}$ & $0.307^{* *}$ & \\
\hline FC3 & $0.358^{* *}$ & $0.450^{* *}$ & $0.373^{* *}$ & \\
\hline FC4 & $0.378^{* *}$ & $0.436^{* *}$ & $0.345^{* *}$ & \\
\hline VL1 & $0.358^{* *}$ & $0.402^{* *}$ & $0.359^{* *}$ & $0.653^{* *}$ \\
\hline VL2 & $0.409^{* *}$ & $0.491^{* *}$ & $0.366^{* *}$ & \\
\hline VL3 & $0.374^{* *}$ & $0.383^{* *}$ & $0.406^{* *}$ & \\
\hline VL4 & $0.389^{* *}$ & $0.395^{* *}$ & $0.333^{* *}$ & \\
\hline & & & & \\
\hline
\end{tabular}

\section{TABLE IV}

CORRELATION (PEARSON's) AMONG BEHAVIORAL INTENTION (BI) AND USE BEHAVIOR (UB)

\begin{tabular}{|r|r|r|r|c|}
\hline & UB1 & UB2 & UB3 & UB (SUM) \\
\hline FC1 & $0.396^{* *}$ & $0.351^{* *}$ & $0.376^{* *}$ & $0.583^{* *}$ \\
\hline FC2 & $0.310^{* *}$ & $0.364^{* *}$ & $0.310^{* *}$ & \\
\hline FC3 & $0.408^{* *}$ & $0.292^{* *}$ & $0.370^{* *}$ & \\
\hline FC4 & $0.341^{* *}$ & $0.312^{* *}$ & $0.335^{* *}$ & \\
\hline
\end{tabular}

**. Correlation is significant at the 0.01 level (2-tailed).

\section{REGRESSION BASED MODERATION ANALYSIS (MODERATED MULTIPLE REGRESSION)}

Moderated Multiple Regression analysis was applied to identify the effect of Precipitating Events (PEV) on the relation between Behavioral Intention (BI) and Use Behavior (UB) of MFS Users

Outcome variable: Use Behavior (UB)

TABLE V

MODEL SUMMARY

\begin{tabular}{|c|c|c|c|c|c|c|}
\hline $\mathrm{R}$ & $\mathrm{R}^{2}$ & $\mathrm{MSE}$ & $\mathrm{F}$ & $\mathrm{df1}$ & $\mathrm{df} 2$ & $\mathrm{p}$ \\
\hline 0.7513 & 0.5645 & 2.7067 & 360.8067 & 3 & 835 & 0 \\
\hline
\end{tabular}

TABLE VI

MODEL

\begin{tabular}{|c|c|c|c|c|c|c|}
\hline & coeff & $\mathrm{se}$ & $\mathrm{t}$ & $\mathrm{p}$ & LLCI & ULCI \\
\hline Constant & 10.567 & 0.063 & 167.6 & 0 & 10.44 & 10.69 \\
\hline BI & 0.4523 & 0.033 & 13.362 & 0 & 0.385 & 0.518 \\
\hline PEV & 0.4063 & 0.034 & 11.782 & 0 & 0.338 & 0.473 \\
\hline $\begin{array}{l}\text { Interaction } \\
\text { (BI X PEV) }\end{array}$ & -0.0055 & 0.007 & -0.7623 & 0.446 & -0.019 & 0.008 \\
\hline
\end{tabular}


Applying the coefficient values from Table VI, (1) can be rewritten as following:

$\hat{Y}=10.567+0.4063 X+0.4523 W-0.0055 X W$

In the above equation the coefficient of interaction (XW) is insignificant [34].

TABLE VII

TEST(S) OF HIGHEST ORDER UNCONDITIONAL INTERACTION(S):

\begin{tabular}{|c|c|c|c|c|c|}
\hline & $\mathrm{R}^{2}$-chng & $\mathrm{F}$ & $\mathrm{df1}$ & $\mathrm{df2}$ & $\mathrm{p}$ \\
\hline $\mathrm{X} * \mathrm{~W}$ & 0.0003 & 0.5812 & 1 & 835 & 0.4461 \\
\hline
\end{tabular}

Focal predict: Behavioral Intension (X)

Moderation variable: Precipitating Events (W)

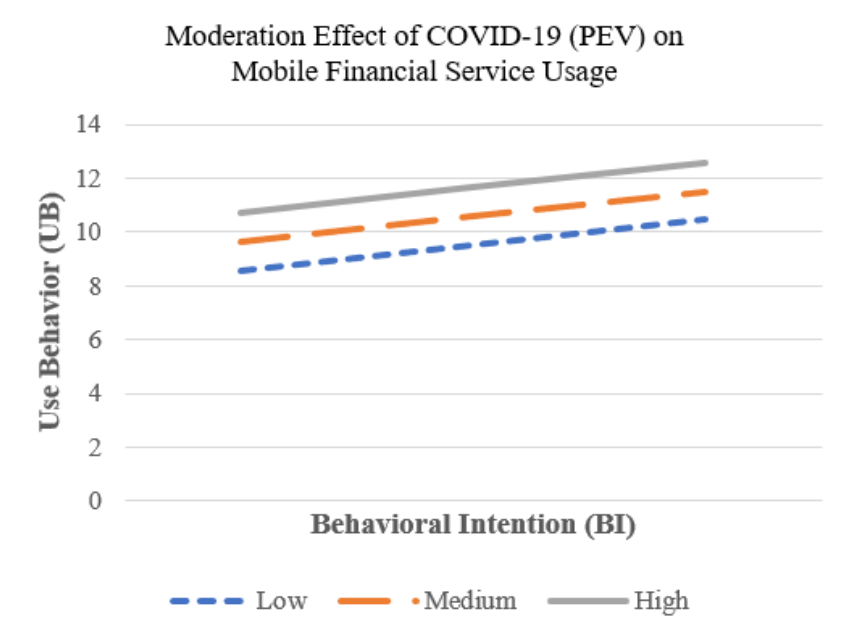

Fig. 2: Moderation effect of Precipitating Event (COVID-19) on Behavioral Intention towards Use Behavior among Mobile

Finance Services (MFS) Users of Bangladesh

Fig. 2 depicts the effects of moderation in three levels and since all the lines are parallel, it indicates that the moderation impact of COVID-19 on the relationship Behavioral Intention and Use Behavior is non-existence [35].

D. Hypothesis and Tests

TABLE VIII

HYPOTHESES: EFFECT OF FACTORS ON BEHAVIORAL INTENTION AND USE BEHAVIOR

\begin{tabular}{|l|l|c|}
\hline Hypotheses & Result & $\begin{array}{l}\text { Pearson's } \\
\text { Correlation } \\
\text { (Table VI \& } \\
\text { VII) }\end{array}$ \\
\hline $\begin{array}{l}\mathrm{H}_{1 \mathrm{~A}}: \text { Performance expectancy } \\
\text { has a significant effect on the } \\
\text { behavioral intention of users }\end{array}$ & Supported & 0.442 \\
\hline
\end{tabular}

\begin{tabular}{|c|c|c|}
\hline $\begin{array}{l}\text { to use Mobile Finance } \\
\text { Services. }\end{array}$ & & \\
\hline $\begin{array}{l}\mathrm{H}_{1 \mathrm{~B}} \text { : Effort expectancy has a } \\
\text { significant effect on the } \\
\text { behavioral intention of users } \\
\text { to use Mobile Finance } \\
\text { Services. }\end{array}$ & Supported & 0.615 \\
\hline $\begin{array}{l}\mathrm{H}_{1 \mathrm{C}} \text { : Social influence has a } \\
\text { significant effect on the } \\
\text { behavioral intention of users } \\
\text { to use Mobile Finance } \\
\text { Services. }\end{array}$ & Supported & 0.607 \\
\hline $\begin{array}{l}\mathrm{H}_{\mathrm{ID}} \text { : Facilitating conditions } \\
\text { have a significant effect on } \\
\text { the behavioral intention of } \\
\text { users to use Mobile Finance } \\
\text { Services. }\end{array}$ & Supported & 0.634 \\
\hline $\begin{array}{l}\mathrm{H}_{1 \mathrm{E}} \text { : Price Value has a } \\
\text { significant effect on the } \\
\text { behavioral intention of users } \\
\text { to use Mobile Finance } \\
\text { Services. }\end{array}$ & Supported & 0.653 \\
\hline $\begin{array}{l}\mathrm{H}_{1 \mathrm{~F}} \text { : Facilitating conditions } \\
\text { have a significant effect on } \\
\text { the Use Behavior of users to } \\
\text { use Mobile Finance Services. }\end{array}$ & Supported & 0.583 \\
\hline
\end{tabular}

TABLE IX

HYPOTHESIS: MODERATION EFFECT OF COVID-19 (PEV) ON BEHAVIORAL INTENTION TOWARDS USE BEHAVIOR

\begin{tabular}{|l|l|l|}
\hline Hypotheses & Result & Values \\
\hline $\mathrm{H}_{2}$ : Precipitating & Not & - 'p' value of \\
Event moderated the & Supported & interaction is \\
relationship between & & insignificant $>$ \\
behavioral intention & & 0.01 (Table VI) \\
and Use Behavior of & & - '0' falls between \\
users to use Mobile & & LLCI and ULCI \\
Finance Services. & & (Table VI) \\
& & - Interaction R $\mathrm{R}^{2}$ \\
& & change is \\
& & insignificant $<0.01$ \\
& & (Table VII) \\
\hline
\end{tabular}

The study hypotheses based on the research framework were tested and the result is presented in the Table VIII \& IX with the following observations:

1) As per the Pearson's Correlation values (Table VIII), all the factors of the research model have positive effect on Use behavior (UB) of MFS users. Among the factors, Price value has the highest effect $(0.653)$ and Performance expectancy has the lowest effect (0.442) [33].

2) It was also found that precipitating event (sudden crisis caused by COVID-19) has no moderation effect (Table V, VI, VIII and Fig. 2) on the relationship between behavioral intention and use behavior of the MFS users [34]. 


\section{CONCLUSION}

Being a developing country, Bangladesh's many development indicators are directly or indirectly related to effective use of Mobile Financial Services. Even though the number of subscriptions has increased over the years in many folds, but the service domains are still very much homogenous. In comparison to developed countries, there are scopes of broadening the services in other dimensions. In the initial study conducted by the Boston Consulting Group (2011) during the beginning of MFS in Bangladesh, many future benefits were predicted, like, increased access to finance facilitates leading entrepreneurship, creation of new business and new jobs, increase tax revenues, enhance e-government services, development of rural society, health care, disaster relief. Many of these are very much implemented and gained popularity among users. But some are still to be implemented or explored.

In this study, in alignment with UTAUT2's postulates, Performance Expectancy (PE), Effort Expectancy (EE), Social Influence (SI), Facilitating Conditions (FC), Price Value (VL) were found to be significantly influential on MFS users' behavioral intention, interestingly price Value; the cost of using this service having the highest influence. The current COVID19 pandemic crisis does not have any impact on the relationship between behavioral intention and use behavior of MFS users. The already existing exponential growth of MFS users may be the reason of this insignificant impact of pandemic.

This study was based on the survey data submitted by users in an online form. The access of online form might have resulted in biasness in demography, where the marginal population might have been ignored. Even though one of the most widely established popular research frameworks was used to assess the use behavior and behavior intention of MFS users; but the COVID-19 situation was completely unprecedented. But at the same time, incorporating COVID-19 impact analysis is also a novelty of this research. It certainly opens a whole new frontier for the nation's users, policy makers, MFS providers and future researchers.

\section{REFERENCES}

[1] Hasan, M. T. (2020). M-Banking: The Transaction Revolution in Bangladesh. Science Research, 8(4), 98.

[2] Bangladesh Telecommunication Regulatory Commission (BTRC) (2021, May). Mobile Phone Subscribers in Bangladesh, May, 2021. http://www.btrc.gov.bd/content/mobile-phonesubscribers-bangladesh-may-2021 (Accessed on July 20, 2021)

[3] United Nations (2021). Department of Economic and Social Affairs - Population Dynamics, 2021.
https://population.un.org/wpp/DataQuery/ (Accessed on April 28, 2021)

[4] Sadia Noor Khan, Maimuna Akter, Rozina Akter. Factors Influencing Adoption and Usage of Mobile Banking: Bangladesh Experience. International Journal of Finance and Banking Research. Vol. 3, No. 1, 2017, pp. 1-12.

[5] Bangladesh Bank (2021). Mobile Financial Services (MFS) comparative summary statement. https://www.bb.org.bd/fnansys/paymentsys/mfsdata.php (Accessed on April 28, 2021).

[6] Bangladesh Telecommunication Regulatory Commission (BTRC) (2021, May). Internet Subscribers in Bangladesh, May 2021. http://www.btrc.gov.bd/content/internet-subscribersbangladesh-may-2021 (Accessed on July 20, 2021)

[7] Bangladesh Bank (2017). An Impact Study on Mobile Financial Services (MFSs) in Bangladesh a Joint Research by Bangladesh Bank and University of Dhaka, December 2017. https://www.bb.org.bd/pub/special/impact_mfs_2709201 8.pdf. (Accessed on April 28, 2021).

[8] The Boston Consulting Group (2011). The SocioEconomic Impact of Mobile Financial Services Analysis of Pakistan, Bangladesh, India, Serbia and Malaysia. https://www.finextra.com/finextradownloads/newsdocs/telenor-bcgmobilereport.pdf (Accessed on April 28, 2021)

[9] Islam, S.R.\& Tareq, M. (2017), "A Study on the Macro Economic Antecedents and Trends of Mobile Banking Services in Bangladesh". In: Xu J., Hajiyev A., Nickel S., Gen M. (eds) Proceedings of the Tenth International Conference on Management Science and Engineering Management. Advances in Intelligent Systems and Computing, Vol. 502. Springer, Singapore

[10] Islam, M. S., Karia, N., Soliman, M. S. M., Fouji, M. H., Khalid, J., \& Khaleel, M. (2017). Adoption of mobile banking in Bangladesh: a conceptual framework. Review of Social Sciences, 2(8), 01-08.

[11] Venkatesh, V., Thong, J.Y.L. and Xu, X. (2012). Consumer acceptance and use of information technology: extending the unified theory of acceptance and use of technology. MIS Quarterly, Vol. 36 No. 1, 157-178.

[12] Moghavvemi, S.; Mohd Salleh, N.A.; Zhao, W. and Mattila, M.M. (2012). The Entrepreneur's Perception of Information Technology Adoption: An Empirical Analysis of the Role of Precipitating Events on Usage Behavior. Innovation: Management, Policy \& Practice. 14(3): 220-235.

[13] Institute of Epidemiology, Disease Control and Research (IEDCR) (2020). Covid-19 Vital Statistics. IEDCR. https://iedcr.gov.bd. Last Access 23-07-2021.

[14] Ahmed, M. (2020). Tertiary Education during Covid-19 and Beyond. The Daily Star. https://www.thedailystar.net/opinion/news/tertiaryeducation-during-covid-19-and-beyond-1897321. Last Access 23-07-2021.

[15] Ahamed, F. (2021). Macroeconomic Impact of Covid-19: A case study on Bangladesh. IOSR Journal of Economics and Finance (IOSR-JEF), 12(1), 2021.. 
[16] Lin, Z., \& Theingi, H. (2019). extended utaut2 model on factors influencing of mobile commerce acceptance in Yangon, Myanmar. AU-GSB e-journal, 12(2), 3-18.

[17] Venkatesh, V.; Morris, M.G.; Davis, G.B. and Davis, F.D. (2003). User Acceptance of Information Technology: Toward a Unified View. MIS Quarterly. 27(3): 425-478.

[18] Maldonado, U. P. T., Khan, G. F., Moon, J., \& Rho, J. J. (2011). E-learning motivation and educational portal acceptance in developing countries. Online Information Review.

[19] Fidani A and Idrizi F (2012). Investigating students' acceptance of a learning management system in university education: A structural equation modeling approach. ICT Innovations, 5th September 2012. Macedonia: ACT, 311320.

[20] Ally M and Gardiner M (2012, 3-5 December). The moderating influence of device characteristics and usage on user acceptance of smart mobile devices. 23rd Australasian Conference on Information Systems (ACIS). Geelong: ACIS, 1-10.

[21] Cohen J, Bancilhon J-M and Jones M (2013). South African physicians' acceptance of e-prescribing technology: an empirical test of a modified UTAUT model. South African Computer Journal 50: 43-54.

[22] LaRose, R., DeMaagd, K., Chew, H. E., Tsai, H. Y. S., Steinfield, C., Wildman, S. S., \& Bauer, J. M. (2012). Broadband adoption| measuring sustainable broadband adoption: an innovative approach to understanding broadband adoption and use. International Journal of Communication, 6, 25.

[23] Krishnaraju V, Mathew SK and Sugumaran V (2013). Role of web personalization in consumer acceptance of egovernment services. Nineteenth Americas Conference on Information Systems, 15-17 August 2013. Chicago: AIS, $1-8$.

[24] Nikou S and Bouwman H (2010, 7-10 January). The diffusion of mobile social network service in China: The role of habit and social influence. 46th Hawaii International Conference on System Sciences (HICSS), 2010. Maui: IEEE, 1073-1081.

[25] Lewis, C. C., Fretwell, C. E., Ryan, J., \& Parham, J. B. (2013). Faculty use of established and emerging technologies in higher education: A unified theory of acceptance and use of technology perspective. International Journal of Higher Education, 2(2), 22-34.

[26] Raman A and Don Y (2013). Preservice teachers' acceptance of learning management software: An application of the UTAUT2 Model. International Education Studies 6(7), 157-164.

[27] Krueger, N. and Brazeal, D.V. (1994). Entrepreneurial Potential and Potential Entrepreneurs. Entrepreneurship Theory and Practice Journal. 18(3), 91-104.

[28] Krueger, N. (2020). Entrepreneurial potential and potential entrepreneurs: 25 years on. Journal of the International Council for Small Business, 1(1), 52-55.

[29] Moghavvemi, S. and Mohd Salleh, N. A. (2011). Entrepreneurs Intention toward IT-Innovation Adoption in Malaysia. Journal of Communications of Global Information Technology (COGIT). 3: 78-86.

[30] Jambulingam, M. (2013). Behavioral intention to adopt mobile technology among tertiary students. World Applied Sciences Journal, 22(9), 1262- 1271.

[31] Islam, M. Z., Kim, P. C. L., \& Hassan, I. (2013). Intention to use advanced mobile phone services (AMPS). Management Decision, 51(4), 824-838.

[32] Schindehutte, M.; Morris, M.H. and Kuratko, D.F. (2000). Triggering Events, Corporate Entrepreneurship and the Marketing Function. Journal of Marketing Theory and Practice. 8(2), 18-30.

[33] D. Davis (1989). Perceived usefulness, perceived ease of use, and user acceptance of information technology. MIS Quarterly, vol.13, no.3, 319-340.

[34] Hayes, A. F., \& Rockwood, N. J. (2017). Regressionbased statistical mediation and moderation analysis in clinical research: Observations, recommendations, and implementation. Behaviour Research and Therapy, 98, 39-57.

[35] Canniatti Ponchio, M., \& Samartini Correio, A. (2018). The simple moderation model and its use in business research. Internext: Revista Electrônica de Negócios Internacionais da ESPM, 13(1).

[36] Sürücü, L., \& Maslakçi, A. (2020). Validity and Reliability In Quantitative Research. Business \& Management Studies: An International Journal, 8(3), 2694-2726.

[37] Tamilmani, K., Rana, N. P., \& Dwivedi, Y. K. (2020). Consumer acceptance and use of information technology: A meta-analytic evaluation of UTAUT2. Information Systems Frontiers, 1-19.

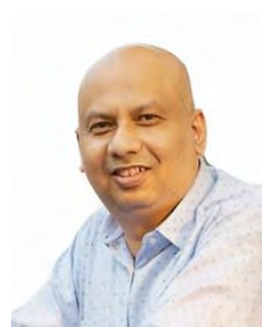

By birth a Bangladeshi, Manzur H Khan is currently pursuing his $\mathrm{PhD}$ at the School of Quantitative Sciences in the Universiti Utara Malaysia (UUM). He completed his Bachelor and Master of Science Degree in physics from the University of Dhaka in 1999. In 2001, he completed his Master of Science degree in business information technology from the University of Westminster, London, UK.

He joined the American International University-Bangladesh (AIUB) as a faculty member of the Department of Computer Science in 2002 and has been teaching numerous undergraduate and postgraduate courses since then. His area of specialization is Management Information Systems with emphasis on System Analysis and Design, Information System Management, Software Engineering, Database and Human Computer Interaction. As additional administrative responsibilities he was appointed as the Coordinator of the Office of Student Affairs in 2005 and later promoted as the Director in 2010.

Mr. Manzur has completed Oracle Database Administrator Certification course in 2004, Sun Java Instructor certification in 2006. Mr. Manzur was a member of the inaugural program of the Education USA Leadership Institute and is an International Exchange Alumni of the Department of State, USA. In 2012, Mr. Manzur worked as an Exchange Faculty under Linnaeus- 
Palme Exchange Program at the Department of Business and Economics Study, University of Gavle, Sweden.

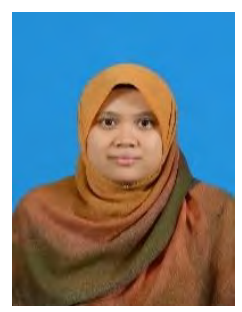

NurAkmal Ahmad Mustaffa is a Senior Lecturer at the Department of Decision Science in the School of Quantitative Sciences, Universiti Utara Malaysia. Her area of specialization and research interests include Deterministic and Stochastic Difference, Supply Chain Management, Markov Decision Process, Discrete Event, Disruption Risk, Inventory Management and Control.

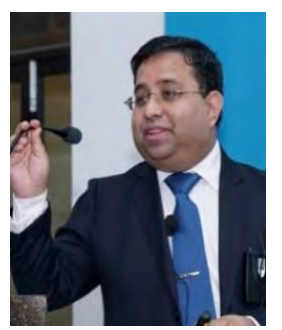

Prof. Dr. Md. Mamun Habib is a Professor at School of Business \& Entrepreneurship (SBE), Independent University, Bangladesh (IUB). In addition, Dr. Habib is the Visiting Scientist of University of Texas - Arlington, USA. Prior to that, he was Associate Professor at BRAC Business School, BRAC University, Bangladesh; Asia Graduate School of Business (AGSB), UNITAR International University, Malaysia; Dept. of Operations Research/Decision Sciences, Universiti Utara Malaysia (UUM), Malaysia and Dept. of Operations Management, American International UniversityBangladesh (AIUB).

He has more than 19 years' experience in the field of teaching as well as in training, workshops, consultancy and research. At present, he is supervising some Ph.D. students at locally and internationally. As a researcher, Dr. Habib published about $160+$ research papers, including Conference Proceedings, Journal articles, and book chapters/books. He serves as the Editor-inChief/Lead Guest Editor/Editor/Editorial Board Member/Reviewer of more than 20 journals, particularly Elsevier (Scopus) and Thomson Reuters (Web of Science) Indexed Journals. In addition, he delivers lecture as Keynote Speaker at $65+$ international conferences in the globe.

His core research areas are supply chain management, production \& operations management, operations research, research methodology. Finally, Dr. Habib is an active member of different professional organizations, including IEEE (Senior Member), IEOM (President, SCM Technical Division), IETI (Senior Member and Board of Director), IRED (Fellow), GRDS (Vice-President), IEB, AIMS, INFOMS, just to name a few. He is involved with QS World University Ranking and Times Higher Education Ranking as an academician. 
Appendix 1: Demography

\begin{tabular}{|c|c|c|c|c|}
\hline Item & Category & Percentage & $\begin{array}{l}\text { Female } \\
\%\end{array}$ & $\begin{array}{l}\text { Male } \\
\%\end{array}$ \\
\hline \multirow[t]{5}{*}{ Age } & $<=20$ & 9.30 & 4.41 & 4.89 \\
\hline & $21-30$ & 73.18 & 21.33 & 51.85 \\
\hline & $31-40$ & 11.20 & 11.20 & 6.44 \\
\hline & $41-50$ & 4.05 & 1.79 & 2.26 \\
\hline & $>50$ & 2.26 & 0.72 & 1.55 \\
\hline \multirow{5}{*}{$\begin{array}{l}\text { Educatio } \\
\text { n Level }\end{array}$} & $<=\mathrm{SSC}$ & 2.86 & 1.31 & 1.55 \\
\hline & $\mathrm{SSC}$ & 1.91 & 0.83 & 1.07 \\
\hline & $\mathrm{HSC}$ & 8.82 & 3.58 & 5.24 \\
\hline & Bachelors & 59.00 & 17.04 & 41.95 \\
\hline & $\begin{array}{l}\text { Masters or } \\
\text { above }\end{array}$ & 27.41 & 10.25 & 17.16 \\
\hline \multirow{6}{*}{$\begin{array}{l}\text { Occupati } \\
\text { on }\end{array}$} & Not Employed & 13.35 & 4.53 & 8.82 \\
\hline & Blue Collar & 2.26 & 0.83 & 1.43 \\
\hline & Student & 40.05 & 12.40 & 27.65 \\
\hline & $\begin{array}{l}\text { Govt. } \\
\text { Employee }\end{array}$ & 6.44 & 2.15 & 4.29 \\
\hline & Private Service & 25.51 & 9.42 & 16.09 \\
\hline & Entrepreneur & 12.40 & 3.69 & 8.70 \\
\hline \multirow{7}{*}{$\begin{array}{l}\text { Monthly } \\
\text { Income }\end{array}$} & $<=10000$ & 46.84 & 17.16 & 29.68 \\
\hline & $10000-20000$ & 19.67 & 5.36 & 14.30 \\
\hline & $20000-50000$ & 18.83 & 5.96 & 12.87 \\
\hline & $50000-100000$ & 9.54 & 2.62 & 6.91 \\
\hline & $\begin{array}{l}100000- \\
200000\end{array}$ & 2.50 & 0.95 & 1.55 \\
\hline & $>200000$ & 1.31 & 0.36 & 0.95 \\
\hline & Blank & 1.31 & 0.60 & 0.72 \\
\hline \multirow[t]{3}{*}{ Location } & Suburban & 15.49 & 6.32 & 9.18 \\
\hline & Rural & 10.73 & 3.22 & 7.51 \\
\hline & $\begin{array}{l}\text { Metropolitan } \\
\text { City }\end{array}$ & 73.78 & 23.48 & 50.30 \\
\hline \multirow[t]{7}{*}{ MFS } & Bkash & 82.96 & 26.34 & 56.62 \\
\hline & Rocket & 17.28 & 4.65 & 12.63 \\
\hline & Nagad & 15.02 & 4.17 & 10.85 \\
\hline & SureCash & 2.86 & 1.31 & 1.55 \\
\hline & iPay & 1.79 & 0.72 & 1.07 \\
\hline & uPay & 1.79 & 1.07 & 0.72 \\
\hline & Others & 7.63 & 2.86 & 4.77 \\
\hline \multirow{7}{*}{$\begin{array}{l}\text { Number } \\
\text { of MFS } \\
\text { used }\end{array}$} & 1 Service & 79.86 & 28.25 & 51.61 \\
\hline & 2 Services & 12.04 & 2.50 & 9.54 \\
\hline & 3 Services & 6.08 & 1.07 & 5.01 \\
\hline & 4 Services & 1.55 & 0.72 & 0.83 \\
\hline & 5 Services & 0.24 & 0.24 & 0.00 \\
\hline & 6 Services & 0.12 & 0.12 & 0.00 \\
\hline & $\begin{array}{l}\text { More than } 6 \\
\text { Services }\end{array}$ & 0.12 & 0.12 & 0.00 \\
\hline
\end{tabular}

Appendix 2: Variables and Items

\begin{tabular}{|c|c|c|}
\hline Variables and Items & Code & References \\
\hline \multicolumn{3}{|l|}{ Performance Expectancy (PE) } \\
\hline $\begin{array}{l}\text { 1. I find mobile payment useful in } \\
\text { my daily life }\end{array}$ & PE1 & {$[11]$} \\
\hline $\begin{array}{l}\text { 2. Using mobile payment helps me } \\
\text { accomplish things more quickly. }\end{array}$ & PE2 & \\
\hline
\end{tabular}

\begin{tabular}{|c|c|c|}
\hline Variables and Items & Code & References \\
\hline $\begin{array}{l}\text { 3. Using mobile payment increases } \\
\text { my productivity }\end{array}$ & PE3 & \\
\hline $\begin{array}{l}\text { 4. Using mobile payment helps my } \\
\text { work to be more effective }\end{array}$ & PE4 & \\
\hline \multicolumn{3}{|l|}{ Effort Expectancy (EE) } \\
\hline $\begin{array}{l}\text { 5. Learning how to use mobile } \\
\text { payment is easy for me }\end{array}$ & EE1 & \multirow[t]{4}{*}[11]{} \\
\hline $\begin{array}{l}\text { 6. My interaction mobile payment } \\
\text { is clear and understandable }\end{array}$ & EE2 & \\
\hline $\begin{array}{l}\text { 7. I find mobile payment easy to } \\
\text { use }\end{array}$ & EE3 & \\
\hline $\begin{array}{l}\text { 8. It is easy for me to become } \\
\text { skillful at using mobile payment }\end{array}$ & EE4 & \\
\hline \multicolumn{3}{|l|}{ Social Influence $(\mathrm{SI})$} \\
\hline $\begin{array}{l}\text { 9. People who influence my } \\
\text { behavior think that I should use } \\
\text { mobile payment }\end{array}$ & SI1 & \multirow[t]{3}{*}[11]{} \\
\hline $\begin{array}{l}\text { 10. People who are important to me } \\
\text { think that I should use mobile } \\
\text { payment }\end{array}$ & SI2 & \\
\hline $\begin{array}{l}\text { 11. People whose opinions matter to } \\
\text { me think that I should use } \\
\text { mobile payment }\end{array}$ & SI3 & \\
\hline \multicolumn{3}{|l|}{ Facilitating Conditions (FC) } \\
\hline $\begin{array}{l}\text { 12. I have required resources } \\
\text { to use mobile payment }\end{array}$ & FC1 & \multirow[t]{4}{*}[11]{} \\
\hline $\begin{array}{l}\text { 13. I have required knowledge } \\
\text { to use mobile payment }\end{array}$ & $\mathrm{FC} 2$ & \\
\hline $\begin{array}{l}\text { 14. Mobile payment is compatible } \\
\text { with other technologies I use }\end{array}$ & $\mathrm{FC} 3$ & \\
\hline $\begin{array}{l}\text { 15. I can get help from others when } \\
\text { difficulties arise in mobile } \\
\text { payment }\end{array}$ & & \\
\hline \multicolumn{3}{|l|}{ Price Value (VL) } \\
\hline $\begin{array}{l}\text { 16. Using mobile payment is } \\
\text { economically feasible }\end{array}$ & VL1 & \multirow[t]{4}{*}[11]{} \\
\hline $\begin{array}{l}\text { 17. Using mobile payment is worth } \\
\text { more than the time and effort } \\
\text { given to it }\end{array}$ & VL2 & \\
\hline $\begin{array}{l}\text { 18. I use mobile payment more } \\
\text { when there are promotional } \\
\text { offers (like, discount, cash back, } \\
\text { etc.) }\end{array}$ & VL3 & \\
\hline $\begin{array}{l}\text { 19. I prefer to pay with mobile } \\
\text { payment than cash }\end{array}$ & & \\
\hline \multicolumn{3}{|l|}{ Behavioral Intention (BI) } \\
\hline $\begin{array}{l}\text { 20. I intend to continue using mobile } \\
\text { payment }\end{array}$ & $\mathrm{BI} 1$ & \multirow[t]{3}{*}[11]{} \\
\hline $\begin{array}{l}\text { 21. I will always try to use mobile } \\
\text { payment in my daily life }\end{array}$ & $\mathrm{BI} 2$ & \\
\hline $\begin{array}{l}\text { 22. I plan to continue using mobile } \\
\text { payment more frequently }\end{array}$ & $\mathrm{BI} 3$ & \\
\hline \multicolumn{3}{|l|}{ Precipitating events (PEV) } \\
\hline $\begin{array}{l}\text { 23. Sudden changes in my daily life } \\
\text { (social or work) influenced my }\end{array}$ & PEV1 & Kruger \\
\hline
\end{tabular}




\begin{tabular}{|l|l|l|}
\hline Variables and Items & Code & References \\
\cline { 1 - 2 } $\begin{array}{l}\text { decision to shift to or use mobile } \\
\text { payment more }\end{array}$ & & $\begin{array}{l}\text { and } \\
\text { Brazeal } \\
(1994)\end{array}$ \\
\cline { 1 - 2 } $\begin{array}{l}\text { 24. } \\
\text { Sudden change in my daily life } \\
\text { (social or work) due to imposed } \\
\text { limitations influenced my } \\
\text { decision to shift to or use mobile } \\
\text { payment more }\end{array}$ & PEV2 & \\
\cline { 1 - 2 } 25. $\begin{array}{l}\text { Sudden change in my daily life } \\
\text { (social or work) due to } \\
\text { opportunity influenced my }\end{array}$ & PEV3 & \\
\hline
\end{tabular}

\begin{tabular}{|l|l|l|}
\hline Variables and Items & Code & References \\
\hline $\begin{array}{l}\text { decision to shift to or use mobile } \\
\text { payment more }\end{array}$ & & \\
\hline Use Behavior (UB) & UB1 & [11] \\
\cline { 1 - 2 } $\begin{array}{l}\text { 26. I use mobile payment for all } \\
\text { possible transaction }\end{array}$ & UB1 & \\
\cline { 1 - 2 } $\begin{array}{l}\text { 27. I use many features of mobile } \\
\text { payment as much as possible }\end{array}$ & UB3 & \\
\cline { 1 - 2 } 28. I depend on mobile payment & \multicolumn{2}{|l|}{} \\
\hline
\end{tabular}

